\title{
Customer Service Expectations from South African Alcoholic Beverage Suppliers in Urban and Rural
} Areas

\author{
Jacques Beukes ${ }^{1}$, Hein Prinsloo ${ }^{2}$, ${ }^{*}$ Theuns G. Pelser ${ }^{3}$ \\ ${ }_{1}^{1}$ NWU School of Business \& Governance \\ ${ }^{2}$ North-West University, Mafikeng Campus, South Africa \\ ${ }^{3}$ University of KwaZulu-Natal, Westville Campus, Durban, South Africa \\ jbeukes@iml.il.co.za, hein.prinsloo@nwu.ac.za, "pelser@ukzn.ac.za
}

\begin{abstract}
South African alcoholic beverage suppliers (SAABS) have to focus their efforts on quality customer service as a means of differentiation. Quality of service is a competitive advantage and serves as a marketing tool for many companies; it also contributes to customer loyalty and retention. Offering quality service is considered an essential strategy for success and survival in today's competitive business market. A commitment to quality must start from the top of any organisation, be it a service delivery company or a manufacturing or merchandising business, and spiral down to the bottom. SAABS need to understand their customers' perceptions of the service offering, their existing relationship with the company and their levels of satisfaction. The study set out to measure the service delivery expectations and realisations of customers that receive delivery from SAABS based on their geographical location. It required the implementation of a descriptive research method. The target population comprised customers of SAABS situated in the Gauteng, Western Cape and North West Provinces of South Africa. A sample size of 926 was realised. The results from the study indicate that customers expect the SAABS to deliver on all five service quality dimensions but fail to do so to their satisfaction. If the SAABS used the proposed customer relationship management (CRM) framework, it can improve on their service delivery and customer service. This, in the long run, will improve customer satisfaction, loyalty and retention.
\end{abstract}

Keywords: Alcoholic beverage suppliers, Customer service, South African alcoholic beverage suppliers, Service quality, SERVQUAL

\section{Introduction}

The concept of service quality is complex, diffuse and abstract, mainly because of the three distinctive features of a service, namely intangibility, heterogeneity and inseparability of consumption (Perez, Abad, Carillo \& Fernandez, 2007). In a global world economy, where alcoholic beverage supplying companies (ABSC) are competitive and consumers very demanding, it is also increasingly difficult to hide inefficiencies in a company's service delivery execution and process. If service companies are unable to provide for the needs and wants of their customers they risk losing them to the competition (Boshoff \& Terblanche, 1997;Sekolanyane, 2004).Companies are focusing on areas in their operations that give them an advantage over their competitors to ensure that they can compete in an increasingly hostile competitive environment (Pelser \& Prinsloo, 2014; Pelser 2001). Abdullah (2005) reports that service quality has been associated with an increase in profitability and is therefore considered as a vital approach to ensure a competitive edge over competitors. Kotler and Armstrong (2001) state that customer satisfaction is closely linked to service quality. Levels of satisfaction is a direct result of the service quality delivered, the higher the service quality the higher the satisfaction.

Over the last 5 financial years (2009-2014) the SAABSI has seen year on year volume growth. Even though there is year on year volume growth it is slowly but surely diminishing. This is a cause of concern to the SAABS in the industry; possible reasons therefore can be established by investigating service delivery. Also in conjunction with the aforementioned problem, there is among employees in the SAABSI a general perception that rural customers are not of the same importance as their urban counterparts. This perceived lack of investment importance is based on return on investment, sales volume, market share and expected profit growth of a SAABS. The perceived tendency automatically creates different levels of service among rural and urban customers.The rural market is further neglected due to the following reasons as supported by numerous executives in the SAABSI:

- Inaccessibility of rural outlets.

- Non-existence of wholesalers or redistribution outlets in rural areas. 
- Limited usage of technology by rural customers.

- Inconsistency of rural customers' liquidity.

- $\quad$ SAABS employees' negative perception regarding the rural market.

- Survival approach to business in the rural market limits the potential for growth.

The perceived tendency could create a limiting effect on the potential growth of the rural alcoholic beverage market. Growth is thus focused on the urban market, although the rural market segment adds up to $40 \%$ (sales as well as customer base) of the total SAABSI market (rural and urban).To create a healthy balance between the urban and rural market it is imperative that the focus be divided between them. Funds and supplier initiatives must benefit the rural market too. The enhanced focus can lead to rural customers expanding and propagating their business and in turn increase SAABS profits. Bad service quality and poor service delivery over time from suppliers can lead to lower customer satisfaction, which in turn can lead to lower customer retention and in the long run a decrease in company profits. Moreover, it diminishes the communities' opportunities to expand and propagate their businesses and contribute to better living conditions.

Diminishing product growth in any company is an indication of commercial deterioration in general, which might lead to possible retrenchments, restructuring or even closure (Garnett \& Pelser, 2007). The problem statement in this study is based on the mentioned negative tendency and read as follows: "The current negative volume growth experienced by the SAABSI pose a possible medium and long term survival threat for the industry". This study focusses on service delivery, in all its dimensions, as a potential resolution.The purpose of this study was to determine service delivery differences between urban and rural customers. The differences between expected service delivery and realized service delivery were established and used in an attempt to develop functional and practical structural guidelines to address these differences. The proposed structure should then assist in improving service delivery to customers, which ought to lead to better customer satisfaction, retention and profit growth.

Research questions: The research questions addressed in this study were the following:

- Do customers of SAABS perceive customer service differently, based on their geographical location (urban vs. rural)?

- What are the perceptions customers have of SAABS regarding service quality in relation to their geographical location (urban vs. rural)?

- Is customer service of equal importance for customers of SAABS within different geographical locations (urban vs. rural)?

- Are there differences between customers' expectations and the realisation of service delivery from SAABS?

- Are customers' experience of actual service delivery received from SAABS is of the same standard within different geographical locations (urban vs. rural)?

\section{Literature Review}

Customer relationship management: Customer relationship management (CRM) is influenced by customer service and customer satisfaction, both these mentioned concepts also has an influence on each other. As Sheth and Uslay (2007), Hoffman and Bateson (2010) and Wang (2011) point out, CRM and customer service are closely related due to the purpose of CRM to build up long-term relationships with customers by offering them a variety of valuable and desirable experiences. It is especially important in service businesses, to understand that customer service is an important part of relationship building for every business. If a business disregard to take advantage of the opportunities offered by developing customer relationships, such a business is bound to suffer the losses that result in the long-term from damaged relationships and the behaviour of dissatisfied customers. Damage can be done to the relationship between businesses and their customers if businesses fail to offer quality service. It is for this reason that CRM is of utmost importance for the sustainability of a business.

There is a wide range of definitions for the concept CRM. Payne and Frow (2006) states that the way CRM is viewed will influence the way in which companies apply and use the concept. McKenzie (2000) and Wang 
(2011) implies that there is no single definition of CRM to which scholars all agree, due to the speed with which CRM is evolving and to the continually changing nature of CRM. A theoretical problem is created for marketing managers and researchers alike due to the lack of agreement on the definition of CRM, as well as practical problems for practitioners who are trying to implement CRM within areas of business that are involved in the maintaining of relationships with customers. Ivens and Shaw (2002) is of the opinion that the most important element in CRM is in which manner a certain business has dedicated itself to maximizing the customer experience and how it is focused on satisfying the needs of their customers.

In his definition, Hill (2007) claims that CRM is the practice of organizing and pursuing all components of an organization's dealings with its customers. This is a view that unfortunately focuses too much on the systems that is used and not enough on the human factor and duration of the relationship. Egan (2008) defines CRM as: "a permanent performance program developed to improve an organization's information of its customers and to sustain access across all the communication channels as well as the establishment of cost-cutting measures". Kotler and Armstrong (2012) define CRM as an overall process of constructing and maintaining profitable customer relationships by delivering superior customer satisfaction and value. This definition is to give priority to the maintaining of long-term relationships by understanding individual customer needs and preferences, and also to add value to a business and supply benefits to its customers. A more comprehensive definition of CRM is supplied by Bligh and Turk (2004). They are of the opinion that the most helpful definition of CRM is one that makes use of a three-tiered approach by incorporating the operational philosophy with the processes and the technologies that are utilized by business.

It is clear that a variety of definitions exist regarding the concept of CRM. There are, however, three main elements on which most authors agree in terms of defining CRM:

(1) CRM is not just intended for use by management neither in the SAABS nor entirely for the marketing department within the company. CRM is instead a culture the entire business should embrace and a strategy that must be implemented across all functions in the business (Anderson \& Kerr, 2002; El Essawy, 2012). This needs to happen from director level to shop floor employees within SAABS.

(2) Businesses needs to understand and manage their customers' needs individually, then only will the business be able to treat each individual customer differently (Greenberg, 2004), and develop personalized relationships in this manner.Within the context of this study the SAABS needs to understand that customers in different COTs need to be handled differently; for this reason, sales teams work in different COTs to increase specialized services. Highly satisfied customers are a direct result of this kind of attention to detail, this in turn motivates these customers to remain with the business over the long term (Chen \& Lin, 2012).

(3) New customers can be attracted by businesses that understand and satisfies customers' needs, current customers can be retained and relationships with these customers can be enhanced into highly profitable, long-term partnerships that add value not only to the customer but also to the business itself (Peelen, 2005; Richards \& Jones, 2006).Through delivering world-class brands and superior service SAABS can attract new customers and ensure they retain their current base; this will ensure a steady stream of profit for the company.

CRM can be categorized into three main types, namely operational CRM, analytical CRM and collaborative CRM. To form relationships with customers are at the base of each of these types. Payne (2006) notes that businesses require practical CRM programs to assist them in identifying valuable customers and to retain not only their loyal and commitment, but also to keep them satisfied with the business product. Payne (2006), Ali (2007) and Malik 2010 explain that operational CRM deals with the automation of the business processes that include customers at points of contact between customers and a business. El Essawy (2012) states that the purpose of operational CRM is to integrate all the events and processes toassists customer access, customer interaction and sales. The automation of the business processes is the main purpose of the specific technology that is used in operational CRM. These business processes integrate the functions and value of efficient services, marketing and sales personnel. Typical business functions involved in operational CRM are marketing automation, sales force automation and service automation. The Marketing automation function allows businesses to develop, budget and execute advertising campaigns. Customer calls through the call centre, directing service calls, and handling customer complaints by supervised employees' forms part of service automation and allows businesses to manage their service operations more effectively (Buttle, 2009). An increase in efficiency in marketing and sales is one of the core benefits of operational CRM for SAABS. 
According to Ali (2007) and El Essawy (2012), analytical CRM provides a basis for analyzing, modeling and evaluating related customer data with a vision to ensure the development of a mutually beneficial relationship between the business and its customers which includes the capturing, storing, processing, extracting, interpreting and implementing of meaningful customer data obtained from the operational part of the business. Analytical CRM assists businesses to obtain accurate and trustworthy information about customer behavior. The quality of the data that is collected is of utmost importance as it determines the quality of information that has been collected through analytical CRM (Tanner et al., 2005). Malik (2010) indicates that customer data storage facilities (data warehouses) that store the information that is gathered from customer's id plays a very important role in this instance. SAABS can obtain information from various sources, such as the customer himself, businesses, market research databases and even the credit bureau. The data collected for use in analytical CRM contains data pertaining to customer behavior, referrals, satisfaction, retention, loyalty and profitability.The focus in collaborative CRM is predominantly on the interactions that take place between customers, businesses and employees (Payne, 2006; Greenberg, 2004). Malik (2010) notes that CRM depends on numerous interactions that take place between businesses and stakeholders. Technology streamlines these interactions by means of predominant electronic communication methods such as e-mail and websites that are dedicated to the receiving and resolving of complaints and dissatisfied customers. While collaborative CRM offers all the benefits contained in one-to-one marketing, it also forces a business to find out exactly what information it is that customers' needs from them and to respond to customer queries, complaints and comments as quick and accurate as possible (El Essawy, 2012).

Customer satisfaction: According to Schiffman and Kanuk (2007) many companies identify relationship marketing programs (RMP) as a tool that can be used to enhance customer loyalty and commitment to their company and services offerings. RMP are very important for service companies as these programs provide the business managers with the required understanding of their customers' needs and support them in adjusting their services according to the diverse needs of their customers (Lovelock \& Wirtz, 2011).Service delivery companies have also realized that relationship marketing (RM) is a key in creating customer satisfaction, customer loyalty and retention (Hoffman et al., 2009). Within marketing customer satisfaction is one of the most considered areas, this can be proved by the fact that over 15000 academic articles have been written on the subject (Hoffman \& Bateson, 2010). Hoffman et al. (2009) state that a great deal of research was conducted on customer satisfaction during the 1970s when consumerism led to a decline in the provision of services, resulting in customer dissatisfaction. According to Dimitriades (2006) and Thomas (2013) customer satisfaction has been a major focus point for business organizations for many years and loyal and dedicated customers contribute to the company's profitability through spending more on the company's products and services. Dimitriades (2006) warns that one should differentiate between customer satisfaction with services and customer satisfaction with goods as they may be influenced by different factors.

Ehigie and Taylor (2009) state that customer-orientated companies' primary focus should be to satisfy their customers. This forms the base for the establishment of lasting and profitable relations with customers. Homburg and Giering (2001) and Kim and Han (2013) confirm that majority of companies attempt to create high levels of customer satisfaction. To be successful and profitable, companies should aim to form and maintain adequate customer satisfaction levels.Work that was done by Parasuraman et al. (1988) between 1985 and 1988 provides a scientific basis for the measurement of customer satisfaction with a service by using the gap between the customers' expectation of performance and their perceived experience of performance.The concept of service quality is not universally understood and is often used as an umbrella term to cover a range of impressions gathered by customers when dealing with businesses. These impressions are important factors that influence buying behavior; businesses can improve on these aspects either through employee training or direct investment in facilities.

An ideal service quality scale is one that is psychometrically sound and robust enough to provide insight to managers for corrective actions in the event of quality shortfalls. The psychometric properties of the SERVQUAL scale have been the subject of considerable research. Work done for example by Cronin and Taylor (1992 and 1994) proposes the "conformation/disconfirmation" theory of combining the "gap" described by Parasuramanet al. (1988) as two different measures: perception and expectation of performance into a single measurement of performance according to expectation. The disconfirmation paradigm is the most widely accepted customer satisfaction model as suggested by Lamb et al. (2009). Many 
customers will not or cannot express their feelings and opinions, and therefore it is important for businesses to measure levels of customer satisfaction so that they are in a position to determine whether or not customers are satisfied.

\section{Methodology}

Quantitative research, using the SERVQUAL model as basis, was used for the empirical study. The survey method was employed to collect the primary data. The sample size selected for the study totals 965 alcoholic beverage customers. This was divided based on the percentage representation within each province.

Target population: The target population comprises customers of SAABS situated in Gauteng, Western Cape and North-West provinces of South Africa. Only licensed customers were used in the proposed study; licensed outlets renew their liquor license every year and sell alcohol legally. Shebeens do not have liquor licenses and have therefore been excluded from the study. These three provinces were used in the study because the majority of the total alcoholic beverage industries customers are situated in these provinces and represent both urban and rural customers. The industry consists of \pm 30000 customers in total. A total of $39.3 \%$ of these customers are based in the rural areas and 60.7\% in urban areas of South Africa. The three provinces feature $29.59 \%$ of the total customer population. The database of customers was obtained from an existing SAABS customer database of the mentioned companies. The total SAABS customers by geographical province are represented in Figure 1.

\section{Figure 1: SAABS customers by geographical area}

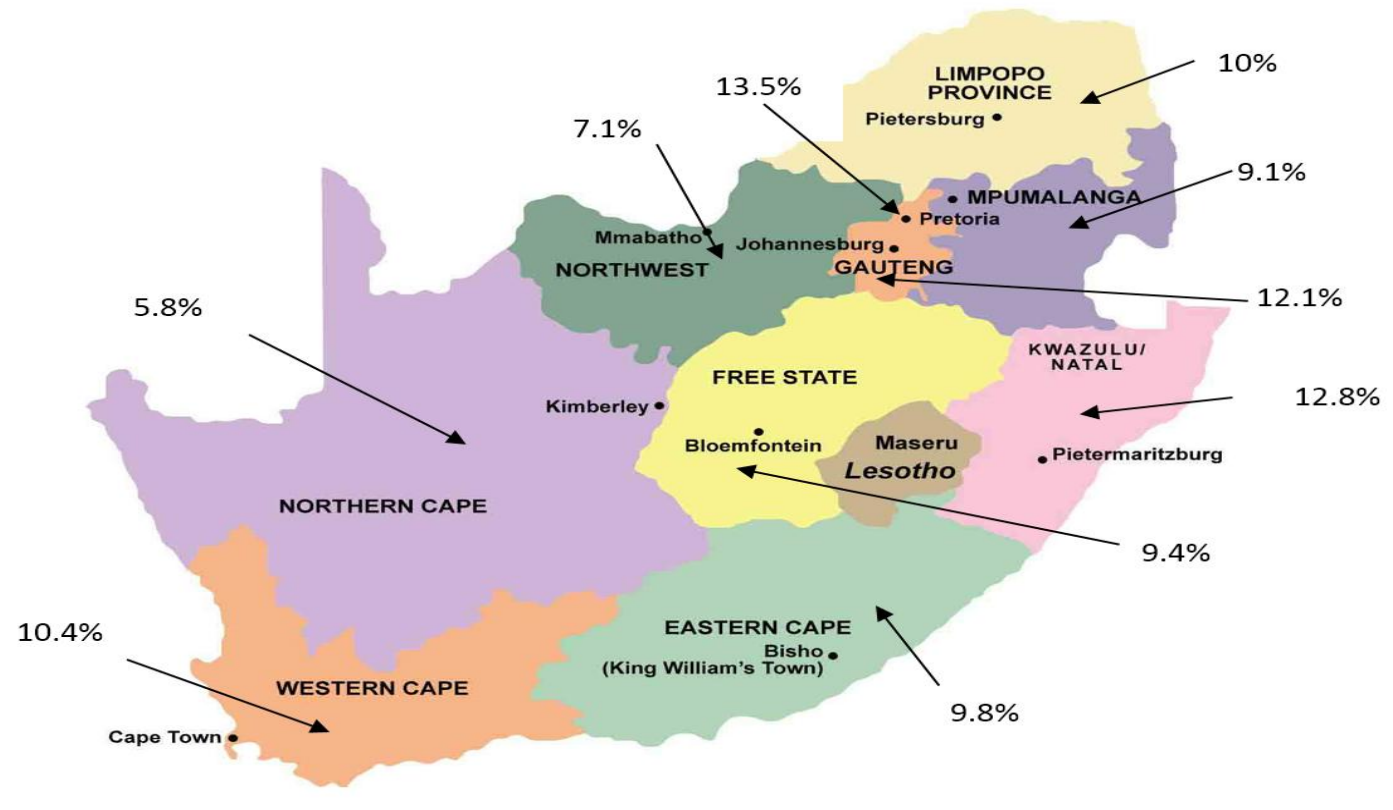

Sampling method: From the given sample frame a non-probability judgment (purposive) sampling method was implemented, which involved choosing sample units subjectively. This study focuses on customers of SAABS. The geographical focus areas within these selected provinces consist of Isando, Chamdor and Soweto in the Gauteng Province; Ottery, Belville and Newlands in the Western Cape Province, and Rustenburg, Mafikeng and Potchefstroom in the North West Province. The selected number of customers within each focus area is graphically depicted in Figure 2 .

The total population of customers that receive alcoholic beverages from SAABS in South Africa adds to \pm 30 000 customers. Total potential customers in the three main geographical provinces total 8877 . This reflects a representation of $29.59 \%$ of the total selected customer population in South Africa. Within this representation Gauteng represents 40.89\%, the Western Cape 35.14\%, and North-West Province 23.96\% within the total population in the three focus provinces. If a confidence level of $90 \%$ and margin of error of 
0.025 are used, then a sufficient target population for the study is 965 respondents. Based on the \% representation of each focus province it adds to 395 respondents in the Gauteng Province, 339 in the Western Cape Province and 231 in the North-West Province. The total number of respondents in these three provinces was then further divided, based on the urban and rural areas compliment in South Africa $(60.7 \%$ urban and $39.3 \%$ rural).

\section{Figure 2: Customers per geographical focus area}

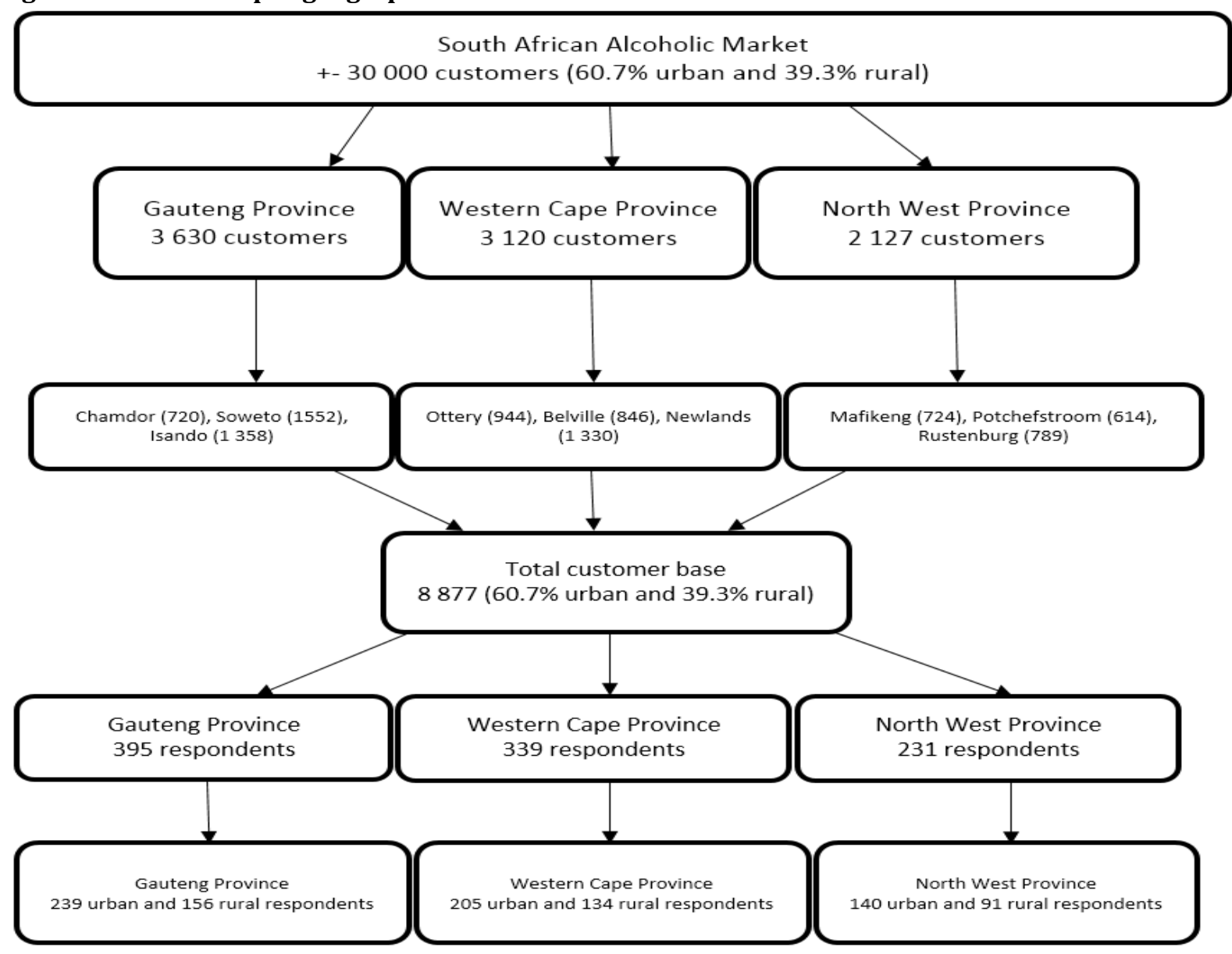

Measuring instrument and data collection method: Data was collected by means of a structured questionnaire. Items in the questionnaire were based on the SERVQUAL model adapted to fit this specific study. All questions were adapted to be applicable to the industry of the proposed study; these were collated in the format of a book with a cover page explaining the purpose, objectives and application of the study. Section A comprised of the demographic details of the respondents. Section B consists of a five point Likert scale, based on the 22 items in the SERVQUAL questionnaire. Responses on this scale range from $1=$ strongly agree to $5=$ strongly disagree.

Reliability and validity: According to Burns and Bush (2010) the success of a research study is greatly influenced by the reliability and validity of the measurement instrument. Iacobucci and Churchill (2010) define a reliable measure as: "one in which the respondent answers in a very similar manner to an identical or near-identical question". Reliable feedback thus indicates the consistency of the measurement instrument.According to Zikmund and Babin (2012) a Cronbach's alpha value between 0.80 and 0.96 indicates very good reliability, a value between 0.70 and 0.80 indicates good reliability, and a value between 0.60 and 0.70 indicates fair reliability. Scales with a Cronbach's alpha value below 0.60 indicate poor reliability. The Cronbach's alpha values obtained for the questionnaire of this study ranged between 0.680 and 0.887 (see Table 1). 
As for face validity, the questionnaire was pretested among a sample of 20 respondents from the target population so that they could assess whether the requisite statements had been included in the questionnaire. In terms of construct validity, a confirmatory factor analysis was conducted for each of the SERVQUAL dimensions measured in the questionnaire.

Table 1: Reliability of service quality dimensions: Expectations

\begin{tabular}{|l|l|c|c|}
\hline \multicolumn{3}{|c|}{ Reliability -Expectations } \\
\hline Factor & Factor label & Cronbach's alpha value & Mean inter-item correlation \\
\hline 1 & Tangibility & 0.860 & 0.610 \\
\hline 2 & Reliability & 0.814 & 0.467 \\
\hline 3 & Responsiveness & 0.640 & 0.309 \\
\hline 4 & Assurance & 0.756 & 0.380 \\
\hline 5 & Empathy & 0.680 & 0.333 \\
\hline & & Reliability -Realisations & \\
\hline Factor & Factor label & Cronbach's alpha value & Mean inter-item correlation \\
\hline 1 & Tangibility & 0.726 & 0.397 \\
\hline 2 & Reliability & 0.887 & 0.613 \\
\hline 3 & Responsiveness & 0.782 & 0.472 \\
\hline 4 & Assurance & 0.853 & 0.539 \\
\hline 5 & Empathy & 0.833 & 0.555 \\
\hline
\end{tabular}

\section{Empirical results}

In order to comprehend the results obtained from the questionnaire fully, it was important to profile the type of respondent that receives delivery service from a SAABS. The demographic profile of respondents that was determined in terms of gender, age, position in the business, highest qualifications, home language and type of business assisted in this regard. Most respondents were situated in Gauteng Province, followed by the Western Cape and North-West Province. From. The majority of male respondents $(63.30 \%, 418$ out of 660$)$ were situated in urban areas. Urban female respondents were slightly more (51.5\%, 137 out of 266) than in rural areas. The majority (50.0\%) of the respondents was aged between 31 and 40 years, followed by the ages between 41 to50 (24.3\%). In the urban areas $50.6 \%$ of the respondents were between the ages of 31 to 40 years, followed by the 41 to 50 age group at $24.5 \%$. In the rural areas $49.1 \%$ of respondents were between the ages of 31 to 40 years, followed by $24 \%$ in the 41 to 50 age groups.

The data also indicates that $81.9 \%$ of the respondents were business owners, $14.9 \%$ were senior managers and 3.2\% middle managers. In both the urban and rural area the majority of respondents were business owners (urban $79.8 \%$ and rural $84.9 \%$ ). As depicted only $34.2 \%$ of the respondents had a post-matriculation qualification, with the majority (43.8\%) of the respondents having only a matriculation certificate. A total of $38.2 \%$ of respondents in the urban areas had a matriculation certificate; in the rural areas $52.3 \%$ had a matriculation certificate. There was also a good distribution between the home language of the respondents, with 23.3\% of respondents' home language being Tswana, 23.1\% being English, 21.4\% being Afrikaans, and $20.1 \%$ being Xhosa. In the urban areas $27.9 \%$ of respondents' home language was English, $22.9 \%$ Afrikaans, $19.3 \%$ Tswana and 18.9\% Xhosa. Within the rural areas 29.4\% respondents' home language was Tswana, 21.8\% Xhosa, 19.1\% Afrikaans and 15.9\% English.

The confirmatory factor analysis model for expectations is indicated in Figure 3. Dimensions were grouped based on collected empirical data and are as follows: Tangibility (E1 - E4), Reliability (E5 - E9), Responsiveness (E10 - E13), Assurance (E14 - E18) and Empathy (E19 - E22). The standardized regression weights $(\beta)$ and correlations between the SERVQUAL constructs based on the items and dimensions for expectations, as indicated in Table 2 are all statistically significant and interpretable. The standardized regression weight for E19 was only 0.088, while all other regression weights were above 0.209. This 
confirms results in exploratory factor analysis that E19 does not load together with other empathy items but is loaded as a unique factor - practical expected empathy.

Figure 3: Confirmatory factor analysis model: Expectations

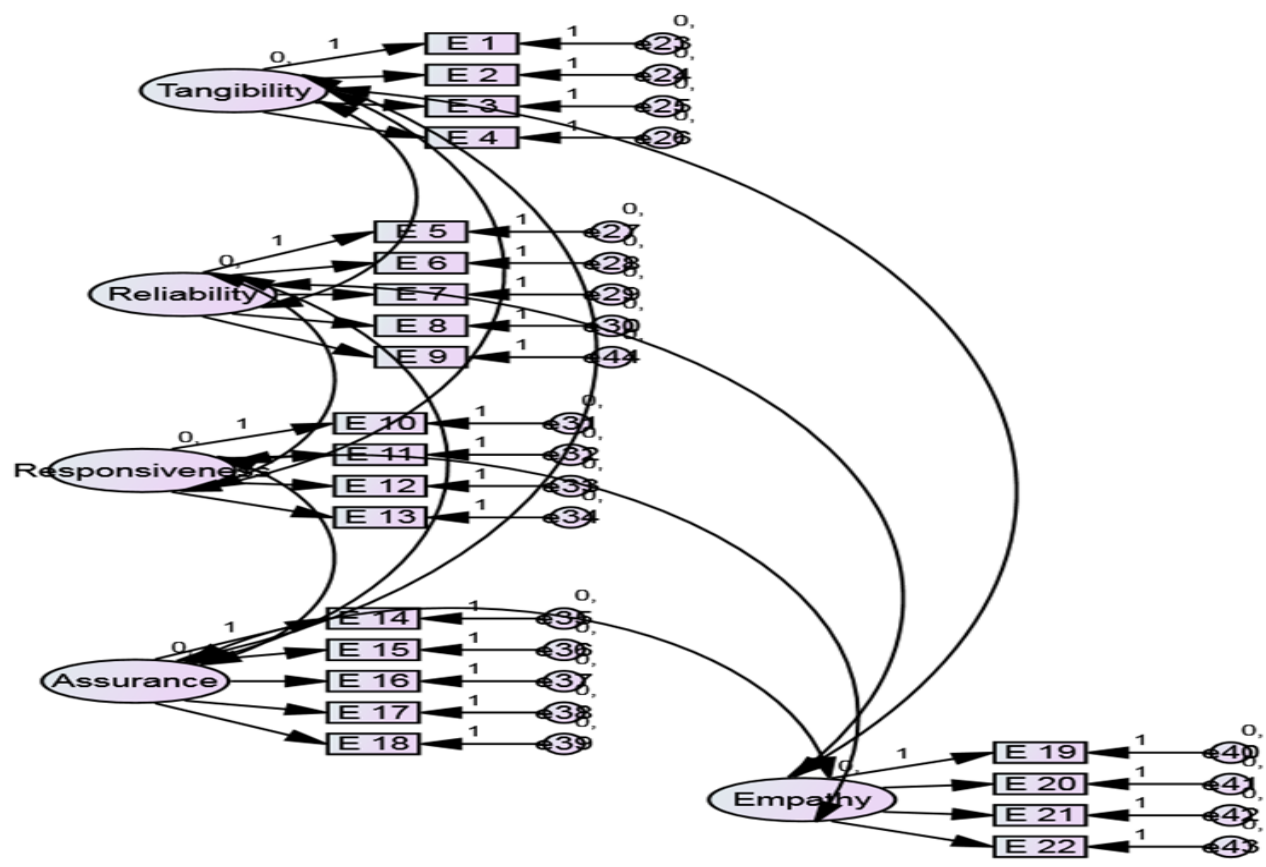

Table 2: Standardized regression weights: Expectations

\begin{tabular}{|c|c|c|c|c|}
\hline \multicolumn{5}{|c|}{ Expectations - Items } \\
\hline & & & p-value & $\beta$ weight \\
\hline E1 & $<---$ & Tangibility & $<0.001$ & 0.758 \\
\hline E2 & $<---$ & T angibility & $<0.001$ & 0.894 \\
\hline E3 & $<---$ & Tangibility & $<0.001$ & 0.709 \\
\hline E4 & $<---$ & T angibility & $<0.001$ & 0.766 \\
\hline E5 & $<---$ & Reliability & $<0.001$ & 0.587 \\
\hline E6 & $<---$ & Reliability & $<0.001$ & 0.829 \\
\hline E7 & $<---$ & Reliability & $<0.001$ & 0.744 \\
\hline E8 & $<---$ & Reliability & $<0.001$ & 0.671 \\
\hline E10 & $<---$ & Responsiveness & $<0.001$ & 0.798 \\
\hline E11 & $<---$ & Responsiveness & $<0.001$ & 0.397 \\
\hline E12 & $<---$ & Responsiveness & $<0.001$ & 0.757 \\
\hline E13 & $<---$ & Responsiveness & $<0.001$ & 0.209 \\
\hline E14 & $<---$ & Assurance & $<0.001$ & 0.530 \\
\hline E15 & $<---$ & Assurance & $<0.001$ & 0.686 \\
\hline E16 & $<---$ & Assurance & $<0.001$ & 0.831 \\
\hline E17 & $<---$ & Assurance & $<0.001$ & 0.711 \\
\hline E18 & $<---$ & Assurance & $<0.001$ & 0.371 \\
\hline E19 & $<---$ & Empathy & $<0.001$ & 0.088 \\
\hline E2O & $<---$ & Empathy & 0.012 & 0.703 \\
\hline E21 & $<---$ & Empathy & 0.012 & 0.650 \\
\hline E22 & $<---$ & Empathy & 0.012 & 0.916 \\
\hline E9 & $<---$ & Reliability & $<0.001$ & 0.571 \\
\hline
\end{tabular}


In Table 3 it is evident that the p-value of three correlations are below 0.05 , which indicates a statistically significant correlation. These were on the Tangibility-Reliability, Empathy-Tangibility and EmpathyAssurance dimensions. All three correlation values of these dimensions were small, which indicates that the correlation between the factors are also small (Tangibility-Reliability $(\mathrm{r}=0.146)$, Empathy-Tangibility $(\mathrm{r}=$ $0.144)$ and Empathy-Assurance $(r=0.139)$. The conclusion can then be drawn that all dimensions of expectation can be seen as different dimensions.

Table 3: Correlation between expectations dimensions

\begin{tabular}{|c|c|c|c|c|}
\hline \multicolumn{5}{|c|}{ Expectations-Dimensions } \\
\hline & & & $\mathrm{p}$-value & Correlation \\
\hline Tangibility & $\langle--\rangle$ & Reliability & $<0.001$ & 0.146 \\
\hline Tangibility & $\mid\langle-\rangle$ & Responsiveness & 0.463 & 0.029 \\
\hline Tangibility & $\mid\langle-\rangle$ & Assurance & 0.681 & -0.016 \\
\hline Empathy & $\langle--\rangle$ & Tangibility & 0.036 & 0.144 \\
\hline Reliability & $\langle--\rangle$ & Responsiveness & 0.540 & 0.025 \\
\hline Reliability & $\mid\langle-\rangle$ & Assurance & 0.463 & 0.029 \\
\hline Empathy & $\mid<->$ & Reliability & 0.063 & 0.107 \\
\hline Responsiveness & $\mid<->$ & Assurance & 0.174 & 0.057 \\
\hline Empathy & $\langle--\rangle$ & Responsiveness & 0.321 & 0.043 \\
\hline Empathy & $\mid<->$ & Assurance & 0.041 & 0.139 \\
\hline
\end{tabular}

Figure 4 displays the urban area and rural area respondents' results as per their expectations of the service quality dimensions of service they receive from SAABS. Again the results are based on the Likert scale used (1 $=$ Strongly agree, $2=$ Agree, $3=$ Neutral, $4=$ Disagree and $4=$ Strongly disagree). Respondents in both the urban and rural areas indicated that they expected good service delivery from the SAABS on all five dimensions of service quality.

\section{Figure 4: Urban versus rural areas service dimensions expectations}

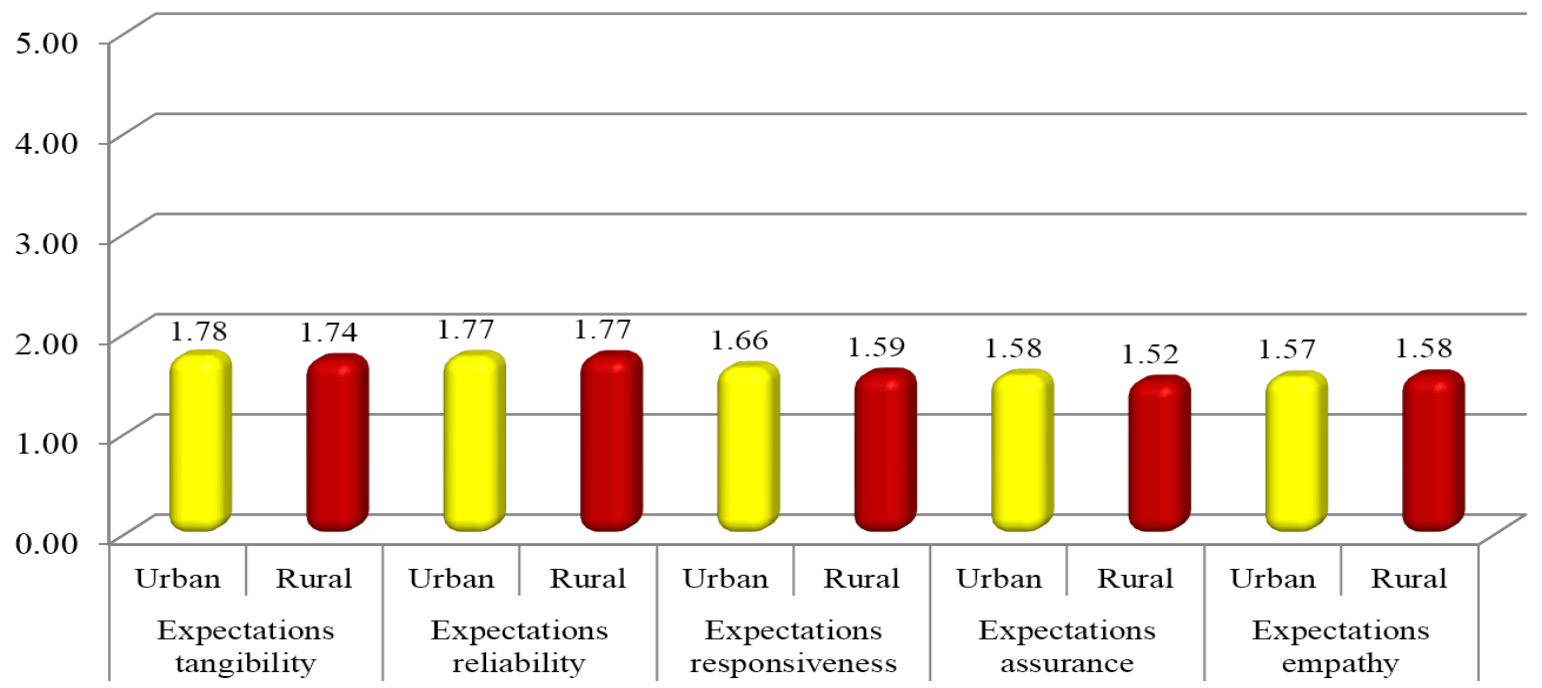

Table 4 displays the effect size and p-values of the T-test done between the urban and rural area respondents on each individual dimension. An 0.2 on the effect size indicates a small practically significant difference, 0.5 indicates a medium practically significant difference and 0.8 a large practically significant difference. There were two dimensions with p-values lower than 0.05 , which indicates statistically significant differences. On 
these two dimensions the effect sizes were 0.16 (expectations responsiveness) and 0.15 (expectations assurance) respectively. These indicate that there is no practically significant difference. There is thus no practically or statistically significant difference between the urban and rural area respondents' expectations of service quality based on the five service quality dimensions as received by SAABS.

Table 4: Urban and rural areas expectations

\begin{tabular}{|c|c|c|c|c|c|}
\hline Dimension & Urban/Rural & Mean & Std. Deviation & p-value & Effect size \\
\hline \multirow{2}{*}{ Expectations Tangibility } & Urban & 1.78 & .49116 & \multirow[b]{2}{*}{0.293} & \multirow[b]{2}{*}{0.07} \\
\hline & Rural & 1.74 & .50644 & & \\
\hline \multirow{2}{*}{ Expectations Reliability } & Urban & 1.77 & .44022 & \multirow[b]{2}{*}{0.984} & \multirow[b]{2}{*}{0.00} \\
\hline & Rural & 1.77 & .47294 & & \\
\hline \multirow{2}{*}{ Expectations Responsiveness } & Urban & 1.66 & .39862 & \multirow[b]{2}{*}{0.014} & \multirow[b]{2}{*}{0.16} \\
\hline & Rural & 1.59 & .38537 & & \\
\hline \multirow{2}{*}{ Expectations Assurance } & Urban & 1.58 & .37441 & \multirow[b]{2}{*}{0.026} & \multirow[b]{2}{*}{0.15} \\
\hline & Rural & 1.52 & .39612 & & \\
\hline \multirow{2}{*}{ Expectations Empathy } & Urban & 1.57 & .37268 & \multirow[b]{2}{*}{0.655} & \multirow[b]{2}{*}{0.03} \\
\hline & Rural & 1.58 & .39141 & & \\
\hline
\end{tabular}

In Figure 5 the results of the urban area and rural area respondents' results as per their realizations of the service quality dimensions of service they receive from SAABS are displayed. Respondents in both the urban and rural areas indicated that they do not receive service delivery from the SAABS on all five dimensions of service quality to their satisfaction. When comparing the rural area respondents' realizations results based on the five service quality dimensions as received from SAABS the trend seems similar to the urban respondents' results. All five dimensions' results returned a mean value near to the Disagree option.

\section{Figure 5: Urban versus rural areas service dimensions realizations}

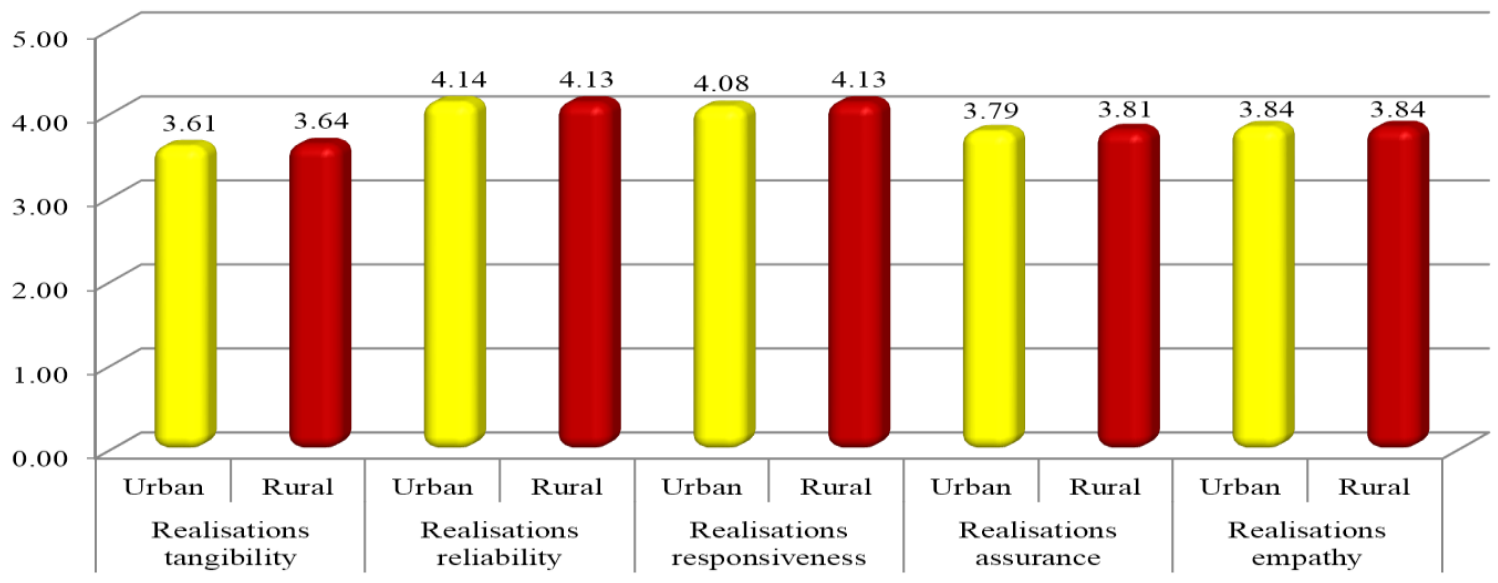


Table 5: Urban and rural areas realizations

\begin{tabular}{|c|c|c|c|c|c|}
\hline Dimension & Urban/Rural & Mean & Std. Deviation & $p$-value & Effect size \\
\hline \multirow{2}{*}{ Realisations Tangibility } & Urban & 3.61 & .44859 & \multirow[b]{2}{*}{0.448} & \multirow[b]{2}{*}{0.05} \\
\hline & Rural & 3.64 & .47678 & & \\
\hline \multirow{2}{*}{ Realisations Reliability } & Urban & 4.14 & .58275 & \multirow[b]{2}{*}{0.949} & \multirow[b]{2}{*}{0.00} \\
\hline & Rural & 4.13 & .59580 & & \\
\hline \multirow{2}{*}{ Realisations Responsiveness } & Urban & 4.08 & .58720 & \multirow[b]{2}{*}{0.157} & \multirow[b]{2}{*}{0.09} \\
\hline & Rural & 4.13 & .53464 & & \\
\hline \multirow{2}{*}{ Realisations Assurance } & Urban & 3.79 & .53397 & \multirow[b]{2}{*}{0.667} & \multirow[b]{2}{*}{0.03} \\
\hline & Rural & 3.81 & .51219 & & \\
\hline \multirow{2}{*}{ Realisations Empathy } & Urban & 3.84 & .54280 & \multirow[b]{2}{*}{0.957} & \multirow[b]{2}{*}{0.00} \\
\hline & Rural & 3.84 & .55571 & & \\
\hline
\end{tabular}

The paired effect size and returned p-values displayed in Table 5 show that there is in fact a statistically significant difference between the means. All the dimensions returned a p-value higher than 0.05 . This indicates that there is no statistical significant difference. Neither is there a practically significant difference.In summary, no practically or statistically significant difference between the urban and rural area respondents' realizations of service quality based on the five service quality dimensions as received by SAABS, could be found.Table 6 illustrates the difference in the respondents' expectations versus their realizations on all five service quality dimensions. Most of the respondents of SAABS felt that the companies must deliver on all five service quality dimensions, but in their expectations indicated the SAABS did not deliver to the full satisfaction of the respondents.

Table 6: Dependent T-test results

\begin{tabular}{|c|c|c|c|c|c|c|}
\hline Dimension & Mean & $\mathbf{N}$ & $\begin{array}{c}\text { Std. } \\
\text { Deviation }\end{array}$ & $\begin{array}{c}\text { Std. Error } \\
\text { Mean }\end{array}$ & P-value & Effect size \\
\hline Expectations tangibility & 1.7611 & 926 & .49737 & .01634 & & \\
\hline Realisations tangibility & 3.6239 & 926 & .45999 & .01512 & $<0.001$ & 3.75 \\
\hline Expectations reliability & 1.7691 & 926 & .45336 & .01490 & \multirow[b]{2}{*}{$<0.001$} & \multirow[b]{2}{*}{4.03} \\
\hline Realisations reliability & 4.1363 & 926 & .58769 & .01931 & & \\
\hline Expectations responsiveness & 1.6331 & 926 & .39443 & .01296 & \multirow[b]{2}{*}{$<0.001$} & \multirow[b]{2}{*}{4.36} \\
\hline Realisations responsiveness & 4.1031 & 926 & .56702 & .01863 & & \\
\hline Expectations assurance & 1.5587 & 926 & .38409 & .01262 & \multirow[b]{2}{*}{$<0.001$} & \multirow[b]{2}{*}{4.26} \\
\hline Realisations assurance & 3.7972 & 926 & .52512 & .01726 & & \\
\hline Expectations empathy & 1.5699 & 926 & .38013 & .01249 & \multirow[b]{2}{*}{$<0.001$} & \multirow[b]{2}{*}{4.15} \\
\hline Realisations empathy & 3.8404 & 926 & .54771 & .01800 & & \\
\hline
\end{tabular}

It is also evident in Table 6 that there is a practically significant difference between the means on all the service delivery dimensions when considering the respondents' responses. All effect sizes were above 3.74; this indicates a large practical significance. The p-values that were returned on all the dimensions were smaller than 0.05 which indicates a statistically significant difference between the respondents' expectations and realizations of service delivery form SAABS.In summary, there are a practically and statistically significant difference between the respondents' expectations and realizations of service quality based on the five service quality dimensions as received by SAABS.

Major findings, implications and recommendations: The following section indicates all the main findings pertaining the study results. Conclusions, implications (if applicable) and recommendations are discussed in relation to the main findings. 
The confirmatory factor analysis supports the fact that the five factors identified through the theoretical exploration of the study are valid and correspond to the SERVQUAL instrument that measures service quality for expectations.

Conclusion 1: It has been observed that the exploratory and confirmatory factor analysis done in confirms the validity of using the SERVQUAL measures that have been identified in this study to determine service quality within the alcoholic beverage supplying industry in South Africa.

Recommendation 1: SAABS can consider using the SERVQUAL measures that have been identified in this study to assess their own levels of service quality.

The five factors confirmed by the confirmatory factor analysis are sufficiently reliable to measure service quality expectations and realizations.

Conclusion 2: The reliability analysis that was done confirms the usage of the SERVQUAL measures that have been identified in this study to determine service quality within the alcoholic beverage supplying industry in South Africa.

Recommendation 2: SAABS can consider using the SERVQUAL measures that have been identified in this study to assess their own levels of service quality.

The study's respondents indicated that the SAABS need to deliver on all the service quality dimensions but fail to do so to their satisfaction.

Main finding B3 is discussed and recommendations are made in detail in combination with main finding B13. respondents' expectations and realizations on all service quality dimensions.

Conclusion 3: There is no statistically or practically significant difference between male and female respondents' expectations and realizations on all five service quality dimensions.

Recommendation 3: SAABS should not differentiate between genders when delivering a service; the same level of service delivery should apply to all genders on all five service quality dimensions.

Respondents do not differ in their expectations or their realizations of a service that they receive from SAABS even though the position that they hold in the business differs.

Conclusion 4: Even though respondents differ in terms of their position in the business, their expectations and realizations of service delivery from SAABS do not differ statistically or practically.

Recommendation 4: SAABS should not give priority of service delivery to customers that hold different positions in their business. This entails (for example) that SAABS should not give better service to an owner of a business than to a middle manager.

B6 There is no statistical difference between the means of respondents with different qualifications.

Conclusion 5: Respondents with different qualifications do not differ in their expectations and realizations of service delivery as received by SAABS.

Recommendation 5: SAABS should not treat customers differently when delivering a service to them even though their qualifications differ. The employees of SAABS should not treat customers differently even though they know what their qualification background is; a person with only a secondary qualification views the importance of service delivery in the same light as a person with a post-graduate degree. 

dimensions expectations and realizations of respondent results based on their home language.

Conclusion 6: Respondents' expectations and realizations of service delivery as received from SAABS do not differ even though their home language does.

Recommendations 6: SAABS should not differentiate between their customers on grounds of home language. Especially sales force and telesales agents should not have pre-conceived ideas of what their customers expect of service delivery from their ABSC even if they differ in home language. The execution of daily service delivery should not differ even though the companies have knowledge of the customers' home language.

There was no statistically significant difference between the respondents' realizations and expectation on all service quality dimensions based on their type of business (COT).

Conclusion 7: Respondents' data did not show any statistically significant difference relating to their expectations and realizations of service delivery from SAABS despite practicing different types of business in the SAABSI

Recommendation 7: This result can be viewed as very important as employees within SAABS view customers within different COT as being of different importance to the industry. A customer within the restaurant and bar COT is usually not viewed as important as a customer in the IRD, SPL COT or tavern COT when it comes to executing service delivery across all five dimensions. This is mainly due to the difference in volume. The finding indicates that even though the customer is in a "less important" COT (as viewed by employees) he or she still views the expected and realized service delivery from SAABS in the same manner as a customer in a more important COT. The main recommendation regarding this finding is that all customers (irrespective of COT) should receive the same level of service delivery from SAASBC across all five service quality dimensions.

There is no practically significant difference between the expectations and realizations of respondents based on their provinces.

Conclusion 8: This study included respondents and customers of SAABS within three provinces in South Africa, namely North West, Gauteng and the Western Cape Province. The statistical results returned in this study indicate that respondents in all three provinces do not differ in their expectations of service delivery from SAABS, with these respondents indicating that they expect the SAABS to deliver on all five service quality dimensions. There is no statistically or practically significant difference between the means of respondents' expectations of service delivery.

Recommendation 8: Due to this significant finding, the recommendation in this instance is several recommendations. Firstly, if the company has an area/region/province approach to training the sales force and customer call centre employees, the customer service training should be standardized. The employees in these roles will then receive the correct applicable training that will enhance their skills and knowledge to be able to serve customers on the same service delivery levels, even if the customers are from different provinces. Secondly, if such a company has a centralized or national approach to the customer service approach and interaction with customers, the SAABS can use the findings from the study to improve/amend or adapt their current customer service training.

There is no practically or statistically significant difference between the urban and rural area respondents' expectations of service quality based on the five service quality dimensions as provided by SAABS.

Conclusion 9: Respondents indicated that they all expect the SAABS to deliver on the five service quality dimensions. What is significant in this result is that the respondents in the urban and the rural area did not 
differ in their opinions about what they expected the SAABS to deliver on. Both areas (urban and rural) tended to agree that the SAABS need to deliver on all five service quality dimensions.

Recommendation 9: SAABS need to focus their attention on all five service quality dimensions to improve their service offering to their customers. The SAABS should not deem any of the dimensions more important than another dimension, as the respondents indicated that there is a minimal difference between what they expected in each dimension (they tend to agree that the SAABS should deliver on all five service quality dimensions). Results do not indicate that one dimension is more important than another dimension. The SAABS must not go about improving on certain dimensions that they feel are important to their company, but should do so holistically and improve on all dimensions.

B11

There is no practically or statistically significant difference between the urban and rural area respondents' realization of service quality based on the five service quality dimensions as received by SAABS.

Conclusion 10: There are no significant differences between urban and rural respondents' realization of SAABS actual service delivery on all five service quality dimensions. They indicated that the SAABS does not deliver to their full satisfaction on all five service quality dimensions. The urban areas realizations do not differ from the rural area realizations. Overall the respondents indicated that the SAABS fail to deliver on all five service quality dimensions.

Recommendation 10: The SAABS need to ensure they deliver on all five service quality dimensions; the data analysis shows they deliver poor customer service to their customers across the board. They need to improve their sales/call centre employees'/operational teams' interaction skills when dealing with customers; customer service training is also encouraged. The SAABS can present a customer service course for their drivers and crew; a further recommendation is made in Recommendation 11 for other service quality dimensions. SAABS should also not deem urban areas customers more important than rural customers and vice versa when delivering a service. Differentiation between urban and rural customers can lead to customer defection, loss of sales and loss of profit.

There is a practically and statistically significant difference between the respondents' expectations and realizations of service quality based on the five service quality dimensions as received by SAABS.

Conclusion 11: Respondents indicated that they expect the SAABS to deliver on the five service quality dimensions but that these companies fail to do so to their satisfaction.The fact that customers of SAABS indicated that they do not receive the expected service delivery to their satisfaction can have numerous implications for the SAABS; these include the following:

- Loss in customer retention.

- Bad company image and reputation.

- Loss in sales, volume and overall profit.

- Reduction in loyal customers.

- Increase in cost to retain customers and to re-establish the image and reputation.

Recommendation 11: Recommendations are made per service quality dimension.

Recommendation 11.1: SAABS can improve on their service levels in respect to the tangibility dimension:

- Companies can improve the look of their fleet (trucks and trailers) overall; this can be budgeted for on a yearly basis.

- They can implement a truck/trailer washing and scrubbing plan to improve the appearance of the trucks.

- Yearly fleet audits to ensure that the appearance of trucks/trailers is maintained can be introduced

- SAABS can upgrade their delivery equipment on a continuous cycle (devices that print invoices/statements when delivering to customers); this will ensure the neatness, correctness and overall modern look of the companies' equipment.

- Companies can ensure the upkeep of the equipment to ensure invoicing can take place correctly. 
- SAABS must also ensure that their crewmen/drivers/sales force and any employee of the company that interacts with customers are neat in their appearance on a daily basis; this includes wearing neat working outfits so that they look presentable when dealing with customers.

Recommendation 11.2: SAABS can improve on their service levels with regard to the reliability dimension:

- Companies need to execute their promises to their customers timeously.

- Employees of SAABS should not make promises to customers that they cannot honor.

- SAABS should resolve customers' problems and complaints timeously and accurately.

- They should ensure that the service is delivered correctly the first time.

- When a time is promised to the customer (being it delivery or resolution time of a complaint or problem) then the employee or company representative needs to ensure he/she adheres to the time promised.

- SAABS must ensure that the equipment they have in place is not faulty, and if found faulty that there is a backup procedure in place to ensure error-free invoicing.

Recommendation 11.3: SAABS can improve on their service levels with regard to the responsiveness dimension:

- Companies need to offer their customers prompt service delivery.

- Employees need to be truthful about when a service will be performed.

- Companies must ensure that all employees that interact with customers have completed a customer service training course.

- They should ensure that employees are always willing to assist customers to resolve queries and complaints and pay attention to questions and requests.

- SAABS can also ensure that their call centre agents do not let people wait for a call to be answered; this can be done by ensuring that when a line is engaged the call is diverted to an open line.

Recommendation 11.4: SAABS can improve on their service levels with regard to the assurance dimension:

- SAABS need to ensure that their employees who interact with their customers have the necessary skills and knowledge to answer customers' questions, queries and complaints.

- They must ensure employees treat customers courteously at all times.

- Employees need to ensure that they give customers individual attention.

- Employees' attitude and behavior must instill confidence into their customers at all times.

- The SAABS need to make sure that their customers feel safe when transacting with the company.

Recommendation 11.5: SAABS can improve on their service levels with regard to the empathy dimension:

- SAABS can ensure that they have convenient operating hours; this will entail having the call centre open and making deliveries to customers at convenient times.

- Employees of the SAABS need to understand the needs of their customers.

- Employees must be sincere in their dealings with customers.

- Call centre and sales staff need to be trained on a customer service course or programs to ensure they entrench good customer service principles.

Limitations of this study and areas for further research: Existing research on CRM and the South African alcoholic beverage supplying industry is limited, which implied that the researchers had to rely on other service industry sources (that are mainly founded in the banking industry) and apply this to the South African alcoholic beverage supplying industry. It was not possible to include all provinces and customers of SAABS, due to the size of the industry in South Africa.The CRM model composed in this study can be tested in other service industries to determine its relevance and applicability. In this study only overall service quality dimensions were evaluated; a similar study can be conducted to establish if there are certain specific items within each dimension that are deemed more important than others.

In the current highly competitive FMCG (Fast Moving Consumer Goods) market there is huge emphasis on service delivery and customer service due to the fact that these two aspects can be the determining factor in overall customer satisfaction and for overall business performance. There has been an overall decline in 
volume growth in the SAABSI; possible reasons could be poor service delivery from the SAABS. The findings of the study confirm this concern in the industry. As depicted in Figure 6 the SAABS can address their poor service delivery by implementing the proposed structure. The proposed structure will ensure that the SAABSC deliver high quality service to their customers.

\section{Conclusion}

In a global world economy, where ABSC (alcoholic beverage supplying companies) are competitive and consumers very demanding, it is increasingly difficult to hide inefficiencies in a company's service delivery execution and process. The primary objective of the study was to determine if differences exist between customer expectations and customer realizations of SAABS (South African alcoholic beverage suppliers)service delivery to their customers, based on their geographical location (rural vs. urban). The SAABS need to establish which service element is important to their customers. As reported in this study, the customers in urban and rural areas indicated that all five service quality elements are deemed important and that customers do not get satisfactory service in all the dimensions. Recommendations on how to improve on these dimensions were given in the form of CRM strategies that SAABSC can implement. Ensuring that these recommendations are implemented will ensure a higher level of service quality and customer satisfaction. This should lead to increased customer retention, sales and profit growth, increased loyalty, the addition of new customers and overall better customer relationship. It is also important to note that if there is any sort of unsatisfactory service delivery or customer unhappiness regarding SAABSC service delivery; it will be regarded as a service failure. If and when there is a service failure, the SAABSC can also use the CRM proposed structure recommendations to ensure the damage is minimal and that they can deliver superior recovery customer service to their customers.

Figure 6: Proposed structure for the SAABSI

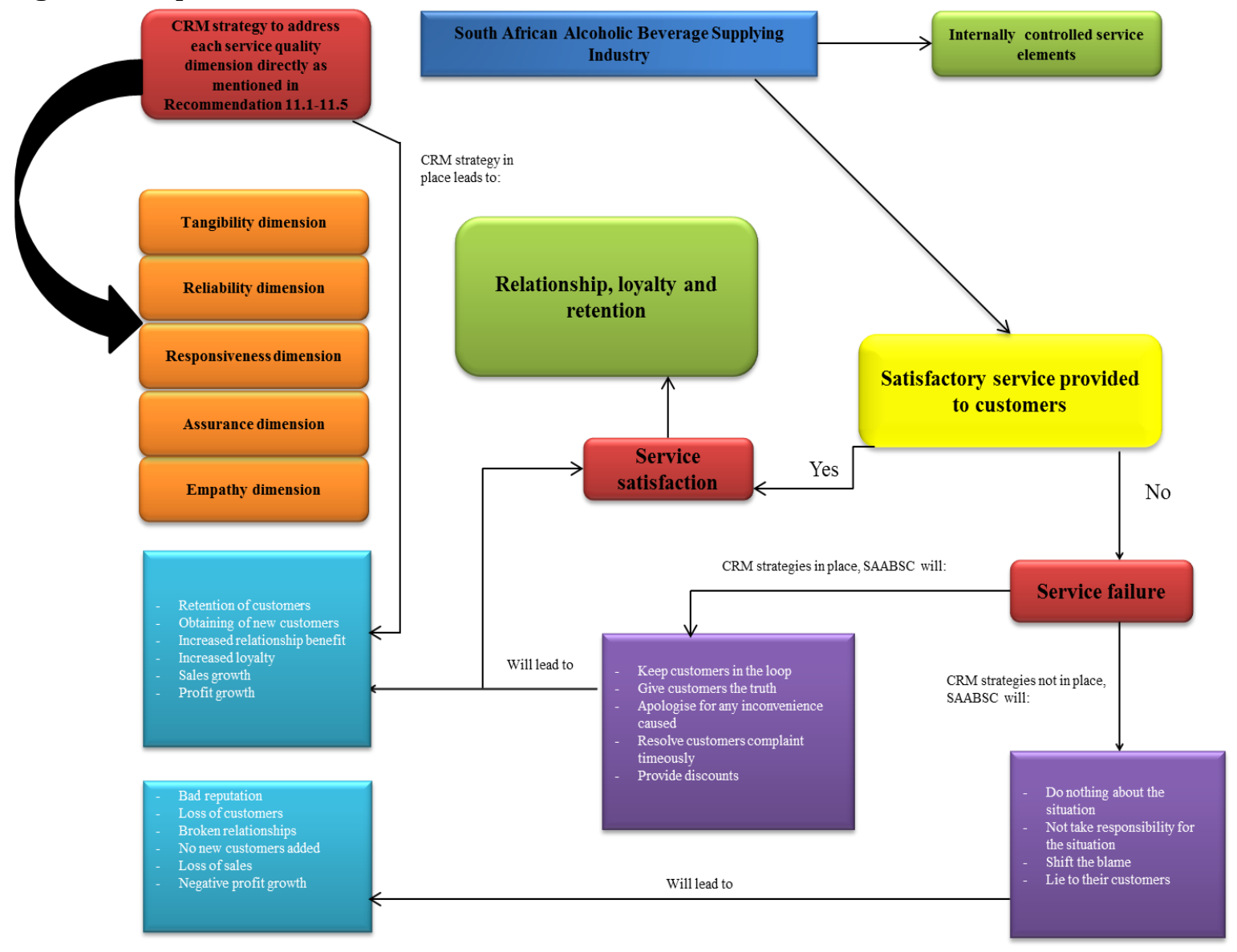




\section{References}

Abdullah, F. (2005). HEdPERF versus SERVPERF: The quest for ideal measuring instrument of service quality in higher education sector. Quality Assurance in Education: An International Perspective, 13(4), 305328.

Ali, I. (2007). Customer relationship management: a qualitative cross-case analysis in the UK and Saudi Arabia.Unpublished Ph.D. thesis. University of Stirling: Stirling.

Anderson, K. \&Kerr, C. (2002). Customer relationship management. New York: McGraw-Hill.

Bligh, P. \&Turk, D. (2004). CRM unplugged: Realizing CRM's strategic value. New Jersey: Wiley.

Boshoff, C. \&Terblanche, N.S. (1997). An instrument to measure service quality in the road freight transport industry. Management Dynamics: Contemporary Research, 6(1), 8-15.

Burns, A.C. \& Bush, R.F. (2010). Marketing Research (6thed.) New Jersey: Prentice-Hall.

Buttle, F. (2009). Customer relationship management: Concepts and technologies. 2nd ed. London: Butterworth-Heinemann.

Chen, C.M. \& Lin, Y.C. (2012). Does better service induce higher profitability? Evidence from Taiwanese Hospitality Industry. International Journal of Hospitality Management 31(4), 1330-1332.

Cronin, J.J. \&Taylor, S.A. (1992).Measuring service quality: A re-examination and extension. Journal of Marketing, 56(3), 55-68.

Cronin, J.J. \& TAYLOR, S.A. (1994). SERVPERF vs. SERVQUAL: Reconciling performance based and perceptions-minus-expectations measurements of service quality. Journal of Marketing, 58(1), 125131.

Dimitriades, Z.S. (2006). Customer satisfaction, loyalty and commitment in service organizations: some evidence from Greece. Management Research News, 29(12), 782-800.

Egan, J. (2008). Relationship marketing: Exploring relational strategies in marketing. (3rd Ed.) Essex, England: Person Education.

Ehigie, B.O. \& Taylor, M. (2009). Managing students' loyalty to school after graduation through relationship marketing. The TQM journal, 21(5), 502-15.

El Essawy, N. (2012). E-customer relationship management readiness in the banking industry: The case of Egypt. Unpublished Ph.D. thesis. Middlesex University: London.

Garnett, A. \& Pelser, T.G. (2007). Organisational barriers to creativity in South African higher education Institutions. South African Journal of Higher Education, 21(1), 50-67.

Greenberg, P. (2004). CRM at the speed of light: Essential customer strategies for the 21st century. (3rd Ed.) New York: McGraw-Hill.

Hill, T.H. (2007). How do you sustain and grow your customer relationships.American Salesman, 52(10), 26.

Hoffman, K.D. \&Bateson, J.E.G. (2010).Services marketing: concepts, strategies and cases. London: SouthWestern Cengage Learning.

Hoffman, K.D., Bateson, J.E.G., Wood, E.H. \&Kenyon, A.J. (2009). Services marketing: Concepts, strategies \& cases. London: South-Western Cengage Learning.

Homburg, C. \&Giering, A. (2001). Personal characteristics as moderators of the relationship between customer satisfaction and loyalty. Psychology \&Marketing, 18(1), 43-66.

Iacobucci, D. \&Churchill, G.A. (2010).Marketing research: Methodological foundations. (10th Ed.) Mason: Cengage.

Ivens, J. \& Shaw, C. (2002). Building great customer experiences. New York: Palgrave.

Kim, P \&Han, J. (2013).Effects of job satisfaction on service quality, customer satisfaction, and customer loyalty: The case of a local state-owned enterprise. WSEAS Transactions on Business and Economics, 10(1), 49-68.

Kotler, P. \& Armstrong, G. (2001). Principles of marketing. (9th ed.) New Jersey: Prentice-Hall.

Kotler, P. \& Armstrong, G. (2012). Principles of marketing. (12th Ed.)New Jersey: Pearson.

Lamb, C.W., Hair, J.F. \&McDaniel, C. (2009). Essentials of marketing. (6th Ed.) Mason: Thomson.

Lovelock, C.H. \& Wirtz, J. (2011). Services marketing: people, technology, strategy. (7th Ed.) Boston: Pearson.

Malik, S.A. (2010). On the use of customer relationship management (CRM) in the banking industry: A qualitative cross-Case analysis between the banks in Pakistan and the UK. Unpublished Ph.D. thesis. University of Manchester: Manchester.

McKenzie, R. (2000.) The relationship-based enterprise: powering business success through customer relationship management. Toronto: McGraw-Hill. 
Parasuraman, A., Zeithaml, V.A. \& Berry, L.L. (1988). SERVQUAL: A multiple-item scale for measuring consumer perceptions of service quality. Journal of Retailing, 61(1), 12-40.

Payne, A. (2006). Handbook of CRM: Achieving excellence in customer management. Oxford: ButterworthHeinemann.

Payne, A. \& Frow, P. (2006).Customer relationship management: from strategy to implementation. Journal of Marketing Management, 22(1/2), 135-168.

Peelen, E. (2005). Customer relationship management. London: Prentice Hall.

Pelser, T.G. \& Prinsloo, J.J. (2014). Technology management and the link with technology strategy and company performance. Journal of Global Business and Technology, 10(2), 1-12

Pelser, T. G. (2001). A strategic management taxonomy of technology and innovation. (Unpublished PhD thesis). Potchefstroom: PotchefstroomseUniversiteitvirChristelikeHoërOnderwys.

Perez, M.S., Abad, J.C.G., Carillo, M.M.C. \& Fernandez, R.S. (2007). Effects of service quality dimensions on behavioural purchase intentions: A study in public-sector transport.Managing Service Quality, 2(17), 134-151.

Richards K.A. \& Jones, E. (2006).Customer relationship management: Finding value drivers. Industrial Marketing Management, 37(2), 120-130.

Schiffman, L.G. \& Kanuk, L.L. (2007). Consumer behavior. (9th Ed.) New Jersey: Prentice Hall.

Sekolanyane, J.E.M. (2004). Measurement of service quality of small business in the Vaal area.Unpublished Ph.D. thesis, North-West University, Potchefstroom.

Sheth, J.N. \& Uslay, C. (2007). Implications of the revised definition of marketing: From exchange to value creation. Journal of Public Policy and Marketing, 26(2), 302-307.

Tanner, J.F., Ahearne, M., Leigh, T.W., Mason, C.H. \& Moncrief, W.C. (2005). CRM in sales-intensive organizations: A review and future directions. Journal of Personal Selling and Sales Management, 25(2), 169-180.

Wang. X.L. (2011).Relationship or revenue: Potential management conflicts between customer relationship management and hotel revenue management. International Journal of Hospitality Management, 31(3), 864-874.

Zikmund, W.G. \& Babin, B.J. (2012). Essentials of marketing research. (5th Ed.) Mason: South-Western. 